\title{
Paradigma Bahagia Itu Mencerdaskan Ikhtiar Membangun Kemerdekaan Belajar Anak Usia Dini
}

\author{
Eka Putri Handayani, Arif Rohman \\ Alifa Kids Center, SD Al-Qur'an An Nur \\ e-mail: amiekafaiq@gmail.com, arifrohman093@yahoo.com
}

Received: 08 Juli 2020; Revised: 21 Agustus 2020; Accepted: 28 Agustus 2020

DOI: http://dx.doi.org/10.37905/aksara.6.2.97-102.2020

\begin{abstract}
Abstrak
Paradigma Bahagia Itu Mencerdaskan bertalian erat dengan program Merdeka Belajar. Penelitian ini bertujuan untuk mengevaluasi penerapan paradigma Bahagia Itu Mencerdaskan dalam kaitannya dengan membangun kemerdekaan belajar anak usia dini. Penelitian ini menggunakan metode evaluasi, dengan model Input-Proses-OutputOutcome (IPOO). Hasil penelitian menunjukkan bahwa paradigma Bahagia Itu Mencerdaskan merupakan langkah baru dalam memahami esensi belajar yang sesungguhnya. Peserta didik hanya bisa belajar dengan baik bilamana dalam suasana hati, iklim belajar dan dukungan lingkungan yang membahagiakan. Dengan belajar dalam situasi bahagia maka akan berdampak pada kecerdasan peserta didik, baik kecerdasan kognitif, afektif maupun psikomotoriknya.
\end{abstract}

Kata kunci: Anak, Belajar, Bahagia, Mencerdaskan

\begin{abstract}
Abstrak
The paradigm of happiness that education is closely related to the Merdeka learning program. This research is intended to evaluate the implementation of the paradigm of happy it is educated in relation to building the freedom of learning early childhood. The evaluation in this study uses qualitative methods, with the IPOO (Input-Process-Output-Outcome) model. The results show that the paradigm of happy that education is a new step in understanding the true essence of learning. Those learners can only learn well when in mood, climate learning, and happy environment support. By learning in happy situations, it will impact the students ' intelligence, both cognitive intelligence, affective, and psychomotor.
\end{abstract}

Keywords: Kids, learn, happy, educate

\section{Pendahuluan}

Bahagia adalah kunci dalam mencerdaskan anak. Anak-anak usia hingga enam tahun kondisi pikirannya masih bersih. Diperlukan upaya guru untuk memberikan perlakuan yang menyenangkan agar proses penyampaian pesan atau pembelajaran bisa diterima dengan baik. Kondisi di lapangan, pendidikan anak usia dini di Indonesia sangat miris. Kebanyakan guru lebih mengacu pada keinginan orang tua tanpa melihat fitrah atau minat bakat yang dimiliki anak-anak. Kebanyakan, orang tua minim edukasi perihal pendidikan anak usia dini. "Hakikatnya dunia anak adalah dunia bermain. Buatlah anak 


$\begin{array}{ll}\text { Volume }: 06 \\ \text { Nomor } & : 03 \\ \text { Bulan } & : \text { September } 2020 \\ \text { Tahun } & : 2020 \\ \text { http } & : / / \text { ejurnal.pps.ung.ac.id/index.php/Aksara }\end{array}$

bahagia di lingkungan dan sekolah. Belajar itu bukan cuma menulis, tapi ketika mereka bergerak, otak mereka juga ikut bekerja.

Di DKI Jakarta, terdapat 1.782 lembaga TK, yang mendidik 53.150 siswa. Terdapat 8156 Tenaga Pendidik (DKI Jakarta dalam Angka, 2019). Guna mewujudkan paradigma "Bahagia itu Mencerdaskan," Kepala Sekolah dan Guru Taman Kanak-kanak (TK) hendaklah mampu memaksimalkan berbagai sumber daya (Resources). Guru dan kepala sekolah hendaklah tertanam dalam dirinya nilai dasar dari Paradigma Bahagia Itu Mencerdaskan. Guru dan Kepala Sekolah hendaklah menjadi: (1) Pribadi yang menyenangkan. (2) Fokus pada Kebahagiaan Anak. (3) Memahami dengan baik bahwa otoritas penuh pada anak. (4) Guru selalu siap memfasilitasi. (5) Mendidik dan membantu anak agar bisa sebagai Pemimpin. (6) Memberikan keteladanan dan pembiasaan (misalnya melalui mendongeng). (7) Menciptakan suasana rileks dan menyenangkan. (8) Guru adalah Kurikulum yang berjalan. (9) Guru hendaklah selalu membangun pola pikir dan membuka horizon pengetahuannya. Dan (10) Guru hendaklah selalu adaptif, memiliki budaya inovatif dari pengalaman belajar yang selama ini digelutinya. Selain itu, guru yang menerapkan paradigma Bahagia Itu Mencerdaskan mampu memanfaatkan segala sumber daya yang ada dan dekat dengan lingkungan sekolah, keluarga dan menjadikan potensi unik anak sebagai dasar dalam menyediakan berbagai pelayanan kepada setiap peserta didik, tanpa kecuali.

Eksistensi guru Taman Kanak-kanak benar-benar sebagai pengganti orang tua. Di sinilah pentingnya paradigma Bahagia Itu Mencerdaskan. Berdasarkan kondisi tersebut, diperlukan seperangkat alat dan cara untuk meningkatkan kapasitas Guru dan kepala Sekolah TK berupa Kegiatan Pendidikan dan Pelatihan (Diklat) yang bertujuan untuk meningkatkan kompetensi Kepala Sekolah dan Guru TK, sehingga benar-benar dapat berperan aktif mewujudkan sebuah pembelajaran yang membahagiakan dan mencerdaskan peserta didik. Sehingga pada akhirnya menjadi pendidik TK Profesional yang mampu mengembangkan kompetensi literasi, numerasi dan pengembangan karakter siswa dengan baik. Sehingga dalam proses pembelajaran Siswa mendapatkan pembelajaran sesuai dengan tahap perkembangannya, dengan media-media pembelajaran yang kreatif dalam suasana menyenangkan. Sehingga sekolah menjadi tempat bermain yang menyenangkan dan dapat mengembangkan 6 Aspek perkembangan anak secara maksimal.

Guna mewujudkan "Bahagia Itu Mencerdaskan" di sekolah-sekolah Taman Kanakkanak, diperlukan lebih banyak guru dan kepala sekolah yang benar-benar memahami dengan baik paradigma itu. Hal ini akan berimplikasi pada program Merdeka Belajar.

Unesco (2016) merilis sejumlah faktor eksternal dan internal yang merusak kebahagiaan pelajar, yang memengaruhi cara orang dewasa memandang tidak hanya kualitas hidup tetapi juga kualitas pendidikan. Pertama, faktor-faktor eksternal seperti meningkatnya ketidaksetaraan, meningkatnya intoleransi, dan bangkitnya ekstremisme kekerasan (Yenina, 2018). Semuanya menciptakan masyarakat yang tidak bahagia. Akibatnya, sekolah juga menghadapi peningkatan kasus intimidasi dari dalam. Sementara pada saat yang sama semakin menjadi sasaran serangan kekerasan dari aktor luar (Beattie, 2015). Dunia yang serba cepat yang didorong oleh kemajuan teknologi juga telah menjadi penuh dengan kompetisi dan 'informasi yang berlebihan', yang mengarah ke perlombaan tanpa henti di mana manusia semakin fokus pada 'angka' - baik dalam hal pembangunan ekonomi suatu negara atau dalam hal hasil pendidikan (Nuraini, 2017). 
Pelaksanaan Pembelajaran (RPP), dan Peraturan Penerimaan Peserta Didik Baru (PPDB) Zonasi.

Empat program pokok kebijakan pendidikan tersebut akan menjadi arah pembelajaran ke depan yang fokus pada peningkatan kualitas sumber daya manusia," Program "Merdeka Belajar" dijabarkan dalam 4 kebijakan yang meliputi:

a. Penilaian USBN komprehensif yaitu penyelenggaraan USBN (Ujian Sekolah Berbasis Nasional) tahun 2020 dilakukan dengan ujian yang diselenggarakan oleh sekolah untuk menilai kompetensi siswa dan dapat dilakukan dalam bentuk tes tertulis atau bentuk penilaian komprehensif seperti portofolio dan penugasan.

b. Penyelenggaraan UN tahun 2021 akan diubah menjadi Asesmen Kompetensi Minimum dan Survei Karakter yang terdiri dari kemampuan literasi, numerasi dan penguatan pendidikan karakter.

c. Penyederhanaan Terkait penyusunan Rencana Pelaksanaan Pembelajaran (RPP) dengan catatan guru secara bebas dapat memilih, membuat, menggunakan, dan mengembangkan format RPP.

d. Zonasi dalam Penerimaan Peserta Didik Baru (PPDB) kebijakan yang lebih fleksibel untuk mengakomodasi ketimpangan akses dan kualitas di berbagai daerah.

Hal tersebut juga akan memberi kesempatan guru untuk memahami tujuan pengembangan diri dan konteks implementasi pada semua peserta didik. Guru merdeka dalam perencanaan, pengajaran dan penilaian. Setiap peserta didik kita butuh hal yang berbeda dari kita. Dengan kata lain, setiap peserta didik butuh kemerdekaan guru untuk memilih dan beradaptasi, Setiap tahun ajaran setiap minggu bahkan setiap hari.

Bertolak dari fenomena tersebut maka dilakukan evaluasi tentang program Bahagia Itu Mencerdaskan yang telah dilaksanakan selama dua tahun di KBTK Alifa Kids Center Pondok Pinang Jakarta dan TKIT Al-Iman Bogor. Evaluasi ini diharapkan mampu memberikan gambaran tentang paradigma Bahagia itu Mencerdaskan dalam mendukung ikhtiar Merdeka Belajar sebagaimana yang saat ini menjadi kiblat Pendidikan di Indonesia.

\section{Metode}

Penelitian ini bertujuan untuk mengetahui gambaran ril paradigma Bahagia itu Mencerdaskan dalam mendukung ikhtiar Merdeka Belajar. Selain untuk melihat keterlaksanaan sepuluh aspek program Bahagia Itu Mencerdaskan, juga diarahkan pada ditemukannya tiga aspek pokok, yaitu keterlaksanaan Permendikbud No. 20/2018, keterlaksanaan program Bahagia itu Mencerdaskan dan praktik baik yang muncul dari program Bahagia Itu Mencerdaskan. Penelitian Evaluasi ini dilaksanakan di KBTK Islam Alifa Pondok Pinang dan TKIT Al-Iman Bogor, mulai bulan Maret s.d. April 2020. Evaluasi menggunakan metode kualitatif, dengan model IPOO (Input-Proses-OutputOutcome). Subjek evaluasi meliputi kepala sekolah, wakil kepala sekolah bidang kurikulum, 10 orang guru pengajar, ketua komite, dan siswa sebanyak 10 orang yang diambil secara acak dari 4 kelas paralel. Data dihimpun melalui observasi, wawancara dan studi dokumen. Data diverifikasi keabsahannya dengan teknik triangulasi, terkait sumber data dan metode yang digunakan. Data dianalisis menggunakan metode deskriptif analisis dengan memaparkan data dan angka serta prosentase dalam bentuk deksriptif kualitatif. 


\section{Hasil dan Pembahasan Hasil Penelitian}

Guna memberikan jawaban atas permasalahan yang hendak dikaji yaitu bagaimana gambaran tentang paradigma Bahagia itu Mencerdaskan dalam mendukung ikhtiar Merdeka Belajar sebagaimana yang saat ini menjadi kiblat Pendidikan di Indonesia. Berdasarkan hasil observasi, diperoleh gambaran data sebagai berikut:

\section{Gambaran Kondisi Ril Sekolah}

a. Guru \& Staf. Terdapat 11 guru yang mengajar di KBTK Islam Alifa, dan sejumlah 10 guru yang mengajar di TKIT Al-Iman. Guru-guru tersebut sebagian besar telah menyelesaikan Pendidikan jenjang S1. Namun demikian semua guru telah mengikuti berbagai jenis kegiatan pengembangan kapasitas seperti pengembangan kompetensi berkelanjutan, pendidikan inklusi, Diklat Penggunaan dan Pemanfaatan APE, diklat merencanakan pembelajaran yang membahagiakan dan berbagai kegiatan lainnya. Kondisi ril guru dan aktivitas guru-guru tersebut dapat divisualkan dalam tabel berikut:

Tabel 1. Kondisi Guru

Kondisi guru dimaksud dapat divisualkan dalam tabel berikut:

\begin{tabular}{lllrrr}
\hline \multirow{2}{*}{ No } & \multirow{2}{*}{ Sekolah } & \multirow{2}{*}{\begin{tabular}{l} 
Jumlah \\
\cline { 5 - 6 }
\end{tabular}} & Guru & Benjang Akademik & \multirow{2}{*}{ S1 } \\
& KBTK IslamAlifa & 11 & 0 & 11 & 0 \\
\hline 1 & TKIT Al-Iman & 10 & 0 & 10 & 0 \\
\hline
\end{tabular}

Tabel 2. Jenis Pelatihan Pengembangan Kapasitas Guru

Jenis Pelatihan yang telah diikuti oleh para guru adalah sebagai berikut:

\begin{tabular}{llll}
\hline \multirow{2}{*}{ No } & \multirow{2}{*}{ Jenis Pelatihan } & \multicolumn{2}{c}{ Jumlah Guru Peserta } \\
& & Alifa & Al-Iman \\
\hline 1 & Pengembangan Kompetensi & 11 & 10 \\
& Berkelanjutan & & \\
2 & Pendidik Inklusi & 10 & 7 \\
3 & Pembuatan dan Pemanfaatan APE & 10 & 8 \\
4 & Membuat Lagu Anak-anak & 11 & 8 \\
5 & STEAM & 8 & 10 \\
6 & Visual Thinking & 11 & 10 \\
7 & Parenting & 11 & 9 \\
8 & Public Speaking & 10 & 10 \\
9 & Penyusunan RPPH & 11 & 11 \\
10 & Study Tour & 11 & 11
\end{tabular}

b. Sekolah dan lingkungannya (fasilitas dan iklim sekolah). Kondisi sekolah cukup mendukung. Selain sekolah memiliki gedung sendiri yang terpisah dari pendidikan lainnya, juga sekolah memiliki berbagai fasilitas yang mendukung pembelajaran yang membahagiakan. Hal ini dikemukakan oleh Kepala KBTK Islam Alifa, Bu Kamilah bahwa: "KBTK Islam Alifa sudah melaksanakan program Bahagia Itu Mencerdaskan. Bekerjasama dengan orang tua murid, 
dengan memberikan edukasi melalui parenting terlebih dahulu. Kondisi sekolah juga sangat mendukung baik berupa iklim sekolah, fasilitas bermain, ruang kelas, dan alat peraga edukatif yang cukup bervariasi sehingga siswa merasa sangat nyaman berada di sekolah serta didampingi oleh guru-guru yang bersahabat dan mengutamakan kepentingan dan kebahagiaan anak. (Wawancara Hari Jum'at, tanggal 10 April 2020).

Sedangkan di TKIT Al-Iman, Kepala Sekolah, Aie Nur Hasanah mengatakan bahwa: "Suasana sekolah sangat mendukung. Selain tempat bermain yang luas dan aman, siswa juga dapat bermain dengan leluasa di halaman sekolah yang luas. Di sini ada Masjid sekolah yang menjadi center of character. Dimana peserta didik di semua jenjang dibangun karakter dan kesolehannya dari masjid sekolah. Selain itu terdapat beragam fasilitas belajar, bermain dan wadah bagi siswa untuk mengeksplorasi bakat, minat dan kesenangan anak-anak. Semua disediakan oleh sekolah, dan didampingi oleh guru-guru profesional dan paham tahap-tahap perkembangan anak. (Wawancara, Hari Kamis, 9 April 2020)

c. Kurikulum \& Praktik baik. Upaya membangun karakter siswa melalui program Bahagia Itu Mencerdaskan di Sekolah KBTK Islam Alifa maupun di TKIT Al-Iman, menurut beberapa narasumber, Jenis kegiatan siswa sebagai berikut:

1) Kegiatan di KBTK Islam Alifa (Wawancara dengan Wiwi Garwini guru KBTK Islam Alifa, Senin, 13 April 2020)

Dikatakan bahwa kegiatan-kegiatan siswa adalah berupa:

a) Pembiasaan shalat dhuha setiap pagi

b) Bermain outdoor

c) Bermain di Sentra (sesuai minat)

d) Bergantian memimpin Doa

e) Pembiasaan Antri setiap wudhu dan mencuci tangan

f) Toilet training (bersama guru)

g) Pembiasaan mengucapkan salam dan ucapan terima kasih

h) Bergantian bercerita di depan kelas

i) Pembiasaan merapikan mainan setelah melakukan kegiatan bermain

j) Menggambar bebas setiap hari sesuai minat.

k) Pembelajaran sesuai tahap perkembangan masing masing anak

1) Morning tea (Parenting) setiap bulan

2) Kegiatan siswa di TKIT Al-Iman (Wawancara dengan Yuliyanti guru TKIT Al-Iman, Selasa, 14 April 2020)

Dikatakan bahwa kegiatan-kegiatan siswa adalah berupa:

a. Shalat Dhuha setiap pagi

b. Pembiasaan mengucapkan salam

c. Bermain di lapangan sebelum masuk sentra

d. Bermain di Sentra (sesuai minat anak)

e. Bermain berkelompok (proyek) setiap Puncak Tema

f. Bergantian menyanyi di depan kelas diiringi guru musik

g. Memainkan alat musik angklung, pianika, seruling (sesuai minat)

h. Bergantian memimpin doa sebelum dan sesudah makan. 
i. Setiap hari disediakan kertas kosong dengan krayon, spidol dan pensil, anak bebas menggambar atau menulis yang dilihat (sesuai minat)

j. Anak anak dapat memilih media pembelajaran yang mereka sukai, sebelumnya sudah di siapkan guru

k. Morning tea (parenting) dihadiri orang tua murid, guru dan kepala sekolah setiap bulan

d. Dukungan Orang Tua dan Masyarakat. Bentuk dukungan orang tua dan masyarakat terhadap penerapan program Bahagia Itu Mencerdaskan di KBTK Islam Alifa dan TKIT Al-Iman adalah sebagai berikut:

Tabel 3. Bentuk Dukungan Orang Tua

\begin{tabular}{clcc}
\hline No & Jenis Dukungan & $\begin{array}{c}\text { KBTK } \\
\text { Islam Alifa }\end{array}$ & $\begin{array}{c}\text { TKIT } \\
\text { Al-Iman }\end{array}$ \\
\hline $\mathbf{1}$ & Respon Komunikasi Timbal Balik & $\mathrm{V}$ & $\mathrm{V}$ \\
$\mathbf{2}$ & Dukungan Kepakaran/Keahlian & $\mathrm{V}$ & $\mathrm{V}$ \\
$\mathbf{3}$ & Dukungan Kegiatan Sekolah & $\mathrm{V}$ & $\mathrm{V}$ \\
$\mathbf{4}$ & Dukungan Finansial & $\mathrm{V}$ & $\mathrm{V}$ \\
$\mathbf{5}$ & Dukungan Study Tour & $\mathrm{V}$ & $\mathrm{V}$ \\
$\mathbf{6}$ & Dukungan Belajar Outdoor & $\mathrm{V}$ & $\mathrm{V}$ \\
$\mathbf{7}$ & Dukungan Lain & $\mathrm{V}$ & $\mathrm{V}$ \\
\hline
\end{tabular}

(Sumber: Buku Induk TKIT Al-Iman Dicatat: Senin, 13 April 2020, dan KBTK Islam Alifa, Dicatat: Selasa, 14 April 2020)

\section{Gambaran Pelaksanaan Program Bahagia Itu Mencerdaskan}

Konsultan Sekolah KBTK Islam Alifa dan TKIT Al-Iman mengemukakan bahwa "terdapat tiga aspek yang dilihat terkait pelaksanaan program Bahagia Itu Mencerdaskan, yaitu dilihat dari aspek legalitas formal, aspek pelaksanaan kegiatan di lembaga pendidikan dan praktik baik yang bisa diambil dari penerapan program tersebut," (Dr. Abdul Kadir, M.Pd. Wawancara, Kamis, 16 April 2020).

a. Pelaksanaan amanat Permendikbud No. 20/2018 tentang penguatan Pendidikan karakter dan Edaran No. 1 tahun 2020 tentang merdeka belajar. Menurut kepala sekolah KBTK Islam Alifa bahwa "penerapan program Bahagia Itu Mencerdaskan muncul jauh hari sebelum diterbitkannya Edaran Pemerintah Nomor 1 tahun 2020 tentang Merdeka Belajar. Pembelajaran Bahagia Itu Mencerdaskan telah mulai dipraktikkan di KBTK Islam Alifa semenjak 2017/2018." Hal senada juga menjadi perhatian bagi kepala TKIT Al-Iman Bogor yang mengatakan hal yang sama. Bahwa penerapan program Bahagia Itu Mencerdaskan telah lama dilaksanakan bahkan jauh hari sebelum Edaran Nomor 1 Tahun 2020 dari Kemendikbud terkait Merdeka Belajar. Namun demikian, Menurut Konsultan Yayasan TKIT Al-Iman dan KBTK Islam Alifa bahwa Edaran Nomor 1 Tahun 2020 tersebut pada prinsipnya sama persis dengan roh dari Bahagia Itu mencerdaskan. Sehingga program Merdeka Belajar ini seperti gayung bersambut dengan program Bahagia Itu mencerdaskan yang selama ini telah dipraktikkan dengan baik di TKIT Al-Iman. 
b. Aspek Pelaksanaan kegiatan. Pelaksanaan kegiatan meliputi, perencanaan kegiatan yang sistematis, mulai dari Program tahunan, semester, bulanan, mingguan dan program harian. Kemudian mengaplikasikan perencanaan tersebut ke dalam kegiatan harian melalui pendampingan.

c. Praktik baik. Praktik baik yang bisa diambil dari pelaksanaan program bahagia itu mencerdaskan adalah, Anak usia dini belajar dengan gembira karena mendapatkan pendidikan yang patut sesuai usianya, Guru lebih mengutamakan kebahagiaan dan minat anak, Guru dan orang tua murid menyadari bahwa usia dini adalah usia bermain, bersenang-senang bersama teman, guru dan orang tua.

\section{Gambaran Hasil Pelaksanaan Program}

a. Anak belajar dengan bahagia, senang berada disekolah dan antusias mengikuti semua kegiatan bermain di sekolah.

b. Kreativitas anak meningkat

c. Kepercayaan diri anak tinggi karena belajar tidak dalam tekanan orang dewasa, tetapi sesuai minat anak.

d. Aspek-aspek perkembangan Anak tercapai dengan baik yaitu Aspek Nilai Moral dan Agama, Kognitif, Sosial Emosional, Fisik motorik, Bahasa dan Seni.

e. Pemahaman awal tentang literasi dan numerasi baik

f. Anak siap untuk melanjutkan pendidikan di sekolah dasar,

g. Orang tua murid memahami aspek perkembangan anak dan tahapan perkembangan anak sehingga tidak menuntut salah satu dari aspek perkembangan anak.

\section{Pembahasan Hasil Penelitian}

Bila dilihat dari pendekatan sistem IPOO (Input, Process, Output dan Outcome) yang dikutip dari Martin, C. and Powell, P. (1992), misalnya bahwa Variabel Penguatan Pendidikan Karakter sebagaimana termaktub dalam Permendikbud Nomor 20 Tahun 2018 dan Edaran Mendikbud Nomor 1 Tahun 2020 dapat dilihat dalam visual berikut:

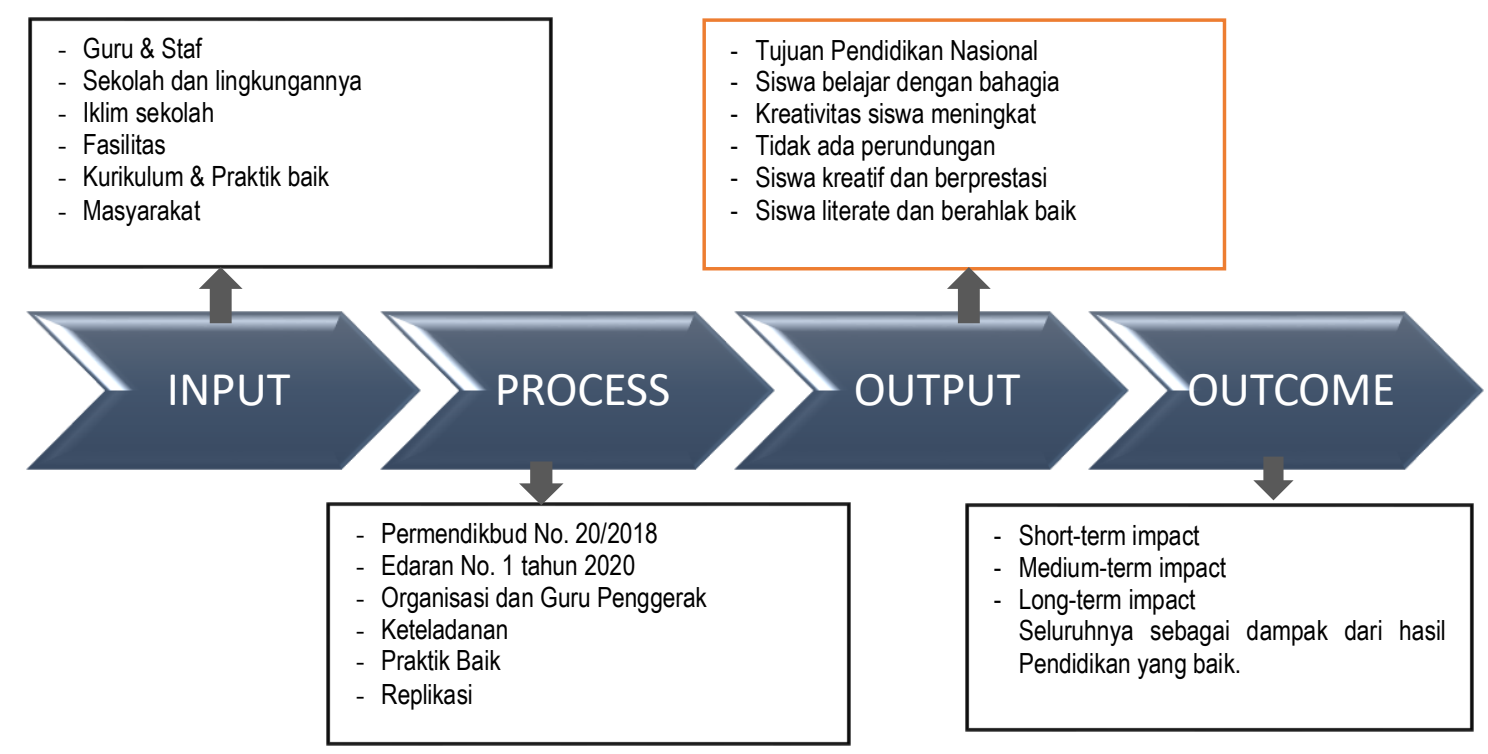




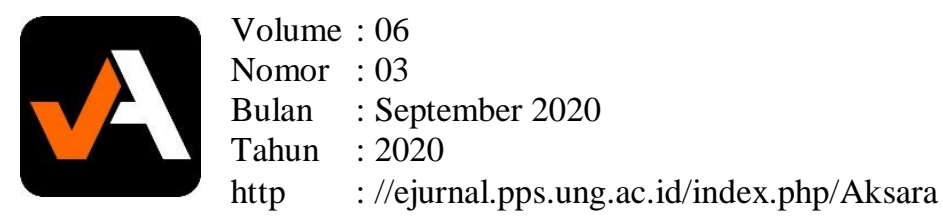

Berdasarkan skema di atas, faktor-faktor input, proses, output dan outcome Pendidikan sebagai akibat dari diberlakukannya Permendikbud Nomor 20 tahun 2018 dan Edaran Kemendikbud Nomor 1 Tahun 2020 dapat dijelaskan sebagai berikut:

a. Input: Saat ini telah tersedia masukan mentah seperti adanya guru dan staf yang mendukung terselenggara dan suksesnya penerapan paradigma Bahagia Itu Mencerdaskan dan memahami dengan baik konsep merdeka belajar. Demikian pula kondisi sekolah dan lingkungan sekolah, iklim dan fasilitas sekolah, kurikulum dan praktik baik yang pernah dilakukan oleh beberapa sekolah yang sudah berhasil serta dukungan masyarakat yang peduli pendidikan yang berkualitas. Selaras dengan sebuah pendapat bahwa Sekolah merupakan tempat bermain yang menyenangkan (Cooper, 2017). Pendapat lain, King \& Datu (2017) bahwa sebuah sekolah yang bahagia perlu didukung oleh instrumental input yang sesuai dengan kebutuhan anak. Rogers memandang bahwa kurikulum yang sesuai, memenuhi unsur praktikal dan strategi yang tepat berorientasi pada penguatan kecakapan-kecakapan klinis dan kompetensi siswa.

b. Proses: sekolah-sekolah di Indonesia melaksanakan dengan baik amanat Permendikbud Nomor 20 tahun 2018 dan Edaran Mendikbud Nomor 1 Tahun 2020. Saat ini pemerintah akan bekerjasama dengan Guru dan Organisasi Penggerak. Para civitas akademik memberikan keteladanan yang baik kepada peserta didik serta beberapa sekolah yang telah berhasil dan menunjukkan praktik baik dapat melakukan replikasi kepada sekolah lainnya. Kondisi ini didukung kebijakan pemerintah tentang Merdeka Belajar, eksistensi Guru dan Organisasi Penggerak sebagaimana tertuang dalam Permendikbud No. 20/2018 tentang penguatan Pendidikan karakter dan Edaran No. 1 tahun 2020 tentang merdeka belajar.

c. Output: Hasil akhir dari Pendidikan di Indonesia adalah tercapainya nilai-nilai yang terkandung dalam Tujuan Pendidikan Nasional (Sisdiknas). Selain itu diharapkan akan tercipta suasana siswa yang belajar dengan bahagia (bahwa belajar itu membahagiakan). Kreativitas dan prestasi siswa meningkat. Tidak terjadi perundungan di sekolah baik yang dilakukan oleh guru maupun siswa serta terciptanya siswa-siswa Indonesia yang memiliki literasi dan berakhlak baik. Berdasarkan hasil penelitian Duckworth and Seligman, (2005) bahwa kebahagiaan anak yang dibangun dari praktik-praktik yang terstruktur dan alamiah turut memperkuat karakter. Sebagai contoh, disiplin diri senantiasa dianggap sebagai salah satu prediktor utama dalam mengukur hasil pendidikan, terlebih pada sekolahsekolah awal.

d. Outcome: Outcome yang berkaitan dengan "tujuan jangka pendek" pada aspek pembelajaran, yaitu terciptanya kualitas lulusan yang memiliki karakteristik: (1) kesadaran, (2) pengetahuan, (3) atitude, (4) skill, (5) opini, (6) aspirasi dan (7) motivasi. Outcome yang berkaitan dengan "tujuan jangka menengah" pada aspek kegiatan yang meliputi aspek-aspek: (1) perilaku, praktik, penentu keputusan, kebijakan dan aksi-aksi sosial di bidang pendidikan. Outcome yang berkaitan dengan "tujuan jangka panjang" pada menekankan pada perubahan kondisi sosial, ekonomi, kependudukan dan lingkungan dalam bidang pendidikan. Seluruhnya menunjukkan dampak atau impact dari serangkaian proses pembelajaran yang baik bagi seluruh rakyat Indonesia. Pendapat O'Connor et.al., (2017) bahwa peran guru dan keluarga sangat penting dalam proses pertumbuhan kepribadian anak. 
Lingkungan yang aman dan anak-anak merasa bebas dan termotivasi untuk berekspresi, memperoleh dukungan dan apresiasi dari sekecil apa pun hasil yang anak perbuat serta dukungan yang membangkitkan semangat ketika siswa menemui kegagalan secara tidak langsung dapat membangun rasa percaya diri anak dan akan berbekas pada kehidupannya setelah dewasa kelak.

\section{Simpulan}

Berdasarkan paparan dan analisis data di atas maka dapat disimpulkan bahwa paradigma Bahagia Itu Mencerdaskan merupakan langkah baru dalam memahami esensi belajar yang sesungguhnya. Bahwa peserta didik hanya bisa belajar dengan baik bilamana dalam suasana hati, iklim belajar dan dukungan lingkungan yang membahagiakan. Dengan belajar dalam situasi bahagia maka akan berdampak pada kecerdasan peserta didik, baik kecerdasan kognitif, afektif maupun psikomotoriknya. Paradigma Bahagia Itu Mencerdaskan bertalian erat dengan program Merdeka Belajar. Keduanya saing mendukung dan berangkat dari satu paradigma bahwa well-being merupakan prasyarat utama dalam sebuah proses pembelajaran. Yaitu pembelajaran yang humanis, adaptif, kreatif dan efektif.

\section{Daftar Pustaka}

Akmal, Yenina, dkk., 2018. Preparing for Parenthood; Parenting Training Module on six Child Development Aspect in East Jakarta, Jurnal Pendidikan Usia Dini, http://journal.unj.ac.id/unj/index.php/jpud. Volume 12 Edisi 2 November 2018. DOI: https://doi.org/10.21009/JPUD.132.12

Beattie, A. Elizabeth, 2015. A Young Child's Perspectives on Outdoor Play: A Case Study from Vancouver, British Columbia, International Journal of Early Childhood Environmental Education, ISSN 2331-0464 (online) Volume 3, Number 1 Winter 2015.

Carl R. Rogers. Freedom to Learn. Columbus, Ohio: Charles E. Merril. Publishing Company

Cooper, Allen, 2017. Nature and the Outdoor Learning Environment: The Forgotten Resource in Early Childhood Education, International Journal of Early Childhood Environmental Education, ISSN 2331-0464 (online) Volume 1, Number 3, Spring 2017.

Duckworth, A. L. \& Seligman, M. E. P (2006). Self-Discipline Gives Girls the Edge: Gender in Self-Discipline, Grades, And Achievement Tes Score. Journal of Educational Psychology. 98(1): 198-208

Gardner, Howard. 1993. Multiple Intelligences. The Theory In Practice. New. York: Basic Books.

Badan Pusat Statistik (2020) Provinsi DKI Jakarta dalam angka 2019 https://jakarta.bps.go.id/publication/2019/08/16/eea4f4b387c3024bb4a3a7fc/pr ovinsi-dki-jakarta-dalam-angka-2019.html. Diakses, 16 April 2020, Pukul 13.40 WIB.

Ismaniar, 2018. Model Permainan Estafet Bait Lagu untuk Meningkatkan Kemampuan Pemusatan Perhatian pada Anak, Jurnal Pendidikan Usia Dini, Volume 12 Edisi 1, April 2018, E-ISSN:2503-0566, DOI: https://doi.org/10.21009/JPUD.121 
King, R. B., \& Datu, J. A. (2017). Happy classes make happy students: Classmates' wellbeing predicts individual student well-being. Journal of School Psychology, 65, 116-128.

Liu, W., Tian, L., Huebner, E. S., Zheng, X., \& Li, Z. (2015). Preliminary development of the elementary school students' subjective well-being in school scale. Social Indicators Research, 120(3), 917-937.

Martin, C. and Powell, P. 1992, Information Systems: A Management Perspective, London, McGraw-Hill.

Nurani, Y., Trias M., 2017. Pengembangan Model Kegiatan Sentra Bermain dalam Mengembangkan Kreativitas Anak Usia Dini, Jurnal Pendidikan Usia Dini. DOI: https://doi.org/10.21009/JPUD.112

Puspita Adhi Kusuma Wijayanti, Rezki Ashriyana Sulistiobudi, 2018. Peer Relation Sebagai Prediktor Utama School Well-Being Siswa Sekolah Dasar, Jurnal Psikologi Vol.17 No.1 April https://www.researchgate.net/_publication/325624245

Rahardjo, Maria M., 2019. How to use Loose-Parts in STEAM? Early Childhood Educators Focus Group discussion in Indonesia, Jurnal Pendidikan Usia Dini, http://journal.unj.ac.id/unj/index.php/jpud, Volume 13 Edisi 2 November 2019, DOI: https://doi.org/10.21009/JPUD.132.08

Rogers, Everett (2003). Diffusion of Innovations, 5th Edition. Simon and Schuste

Susanne A. Denham, Hideko H. Bassett \& Katherine Zinsser, 2018. Early Childhood Teachers as Socializers of Young Children's Emotional Competence, Early Childhood Education Journal, ISSN 1082-3301, Springer, Early Childhood Educ. J, DOI: https://10.1007/s10643-012-0504-2

Suwahono, Dwi Mawanti, 2019. Using Environmentally Friendly Media (Happy Body) in Early Childhood Science: Human Body Parts Lesson, Jurnal Pendidikan Usia Dini, http://journal.unj.ac.id/unj/index.php/jpud, Volume 13 Edisi 2 November 2019, DOI: https://doi.org/10.21009/JPUD.132.06.

Syslová, Zora, 2020. Correction to: The relation between reflection and the quality of a preschool teacher's education performance, International Journal of Child Care and Education Policy, Correction to: Int J Child Care Educ. Policy (2019) 13:4, DOI: https://doi.org/10.1186/s40723-019-0060-y

Teo, Betty, 2020. Early Childhood Educational Management: Managing change in curriculum in early childhood education canters in Singapore to allow for play curriculum, International Journal of Child Care and Education Policy, Correction to: Int J Child Care Educ. Policy (2019) 18:2. DOI: https://doi.org/ 10.1186/s40723-019-0060-y

Unesco (2016) Happy Schools, ISBN: 978-92-9223-542-0 (Electronic Version) UNESCO Open Access Repository (http://www.unesco.org/open-access/termsuse-ccbysa-en). 
Volume : 06

Nomor : 03

Bulan : September 2020

Tahun : 2020

http : //ejurnal.pps.ung.ac.id/index.php/Aksara

276 AKSARA: Jurnal IImu Pendidikan Nonformal 